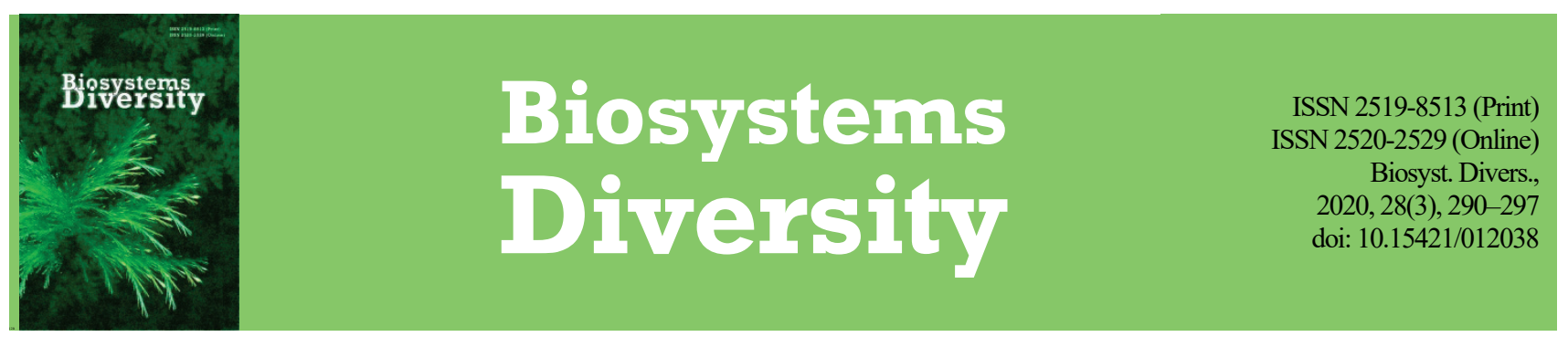

\title{
Fruit and berry plants of forest belts as a factor of species diversity of ornithofauna during the breeding season and autumn migration period
}

\author{
V. V. Pesotskaya*, A. B. Chaplygina*, T. V. Shupova**, R. I. Kratenko* \\ *G. S. Skovoroda Kharkiv National Pedagogical University, Kharkiv, Ukraine \\ **Institute for Evolutionary Ecology of NAS of Ukraine, Kyiv, Ukraine
}

Article info

Received 29.07.2020

Received in revised form

Accepted 03.09.2020

H. S. Skovoroda Kharkiv National Pedagogical University

Alchevsky st., 29, Kharkiv,

61002, Ukraine.

Tel.: +38-050-882-50-86.

E-mail:erapisocka@ukr.net

Institute for Evolutionary Ecolog

of NAS of Ukraine, Lebedeva st.,

37, Kyiv, 03143, Ukraine.

Tel.: +38-095-421-03-42.

E-mail:tv.raksha@gmail.com
Pesotskaya, V. V., Chaplygina, A. B., Shupova, T. V., \& Kratenko, R. I. (2020). Fruit and berry plants of forest belts as a factor of species diversity of ornithofauna during the breeding season and autumn migration period. Biosystems Diversity, 28(3), 290-297. doi:10.15421/012038

During migration, the availability of food that affects the success of bird movements, the nature and timing of their movements, is critical for many bird species. The relationship between migration routes and the ripening of fruit and berry plants along the route is important. Four types of forest belts were studied: wind-blown maple-ash, latticed maple-linden, dense oak-maple-linden, windblown oak-maple-poplar. During the study 43 bird species were identified consuming 9 major fruit and berry plant species: Sambucus nigra, Prumus spinosa, Crataegus laevigata, Rosa canina, Prunus padus, Sorbus aucuparia, Rhammus cathartica, Morus nigra, Prunus cerasus. The highest average number of birds feeding in forest belts ( $4.14 \mathrm{ind} . \mathrm{km})$ was registered in oak-maple-linden dense forest belts, while the lowest number $(1.48 \mathrm{ind} / \mathrm{km}$ ) was recorded in wind-blown maple-ash ones. Maple-linden latticed forest belts characterize the best index data of $\alpha$-diversity of birds. In the summer-autumn diet, succulent fruit are the most important: Starling (Sturnus vulgaris) - 11.8\% of the total number of birds observed to feed on this food resource, Greenfinch (Chloris chloris) $11.3 \%$, Chaffinch (Fringilla coelebs) - 9.3\%, Song thrush (Turdus philomelos) - 7.3\%, Hawfinch (Coccothraustes coccothraustes) $-7.1 \%$, Blackbird (Turdus merula) $-5.4 \% .42$ species of birds were observed to feed on black elderberry. More than half $(51.2 \%)$ of the species composition of birds feeding on fruit and berry plants were migratory birds. Consequently, juicy berries are an important food during bird migrations.

Keywords: migrations of birds; feed; numerical composition; floristic composition.

\section{Introduction}

Each year, billions of seasonal migrants connect the continents, transporting different substances, energy and pathogens between remote communities and ecosystems. Migratory animals change ecology and ecosystems by transporting energy, nutrients and living organisms, as well as by extracting food and becoming prey (Bauer \& Hoye, 2014; Zaifman et al., 2017; Norevik et al., 2019; Koshelev et al., 2020). Consequently, migratory species profoundly alter the dynamics of trophic connections, biocenosis processes and ecosystem functioning as a unique and highly influential component of local biocenosis diversity. The bird migrations that have been most studied (Doren \& Horton, 2018; Schmaljohann, 2018) are those which have been common since the last ice age (Somveille et al., 2020). Bird migration behaviour has taken shape at different times and along different biogeographical routes, some of which are adaptations to new environmental opportunities that have allowed a return to sedentary life style (Dufour et al., 2019).

Today, about $20 \%$ of bird species are migratory and their seasonal movements influence the redistribution of species diversity, which radically changes the composition of the ornithofauna of certain areas. Given their significant movements, migratory birds, in principle, have a wide range of possible breeding and wintering locations, but each species migrates within the limits of its range (Somveille et al., 2019). The feasibility of different routes for birds depends on latitude, migration direction, migration season and geographical location (Muheim et al., 2018). It is already known that annual migration periods vary much less for repeat flights of the same individual than for repeat flights between different individuals, while there have been significant differences in routes for repeat flights of the same individual (Vardanis et al., 2011). Three main bird migration routes to wintering areas in sub-Saharan Africa are known. Overwintering areas and migration routes of different breeding populations can overlap, which is best described as a "weak (diffuse) connection". Migration characteristics, i.e. time, duration, distance and rate of migration, can be surprisingly similar for the three routes despite differences in habitat characteristics (Trierweiler et al., 2014). Global models of the geographical distribution of birds in the world point to the strong spatial diversity of migratory birds, which may explain why they migrate (Somveille et al., 2015; Somveille, 2016). Contemporary migrants are uniquely able to respond to temperature conditions throughout the year, avoid local competition, and reach areas with the best access to food resources by minimizing the distance travelled according to the species' geographical location (Chevallier et al., 2010; Somveille et al., 2019). The peculiarities of bird movements are discussed considering different parameters: meteorological conditions - fog with low clouds, wind direction (Helm et al., 2019; Nilsson et al., 2019; Panuccio et al., 2019; Aurbach et al., 2020); global climate change (Zaifman et al., 2017; Curley et al., 2020). The tendency towards warmer winters in northwestern Europe is leading to a reduction in the distance between suitable wintering areas and breeding sites for many bird species, which has a positive impact on the conservation of chicks from late broods (Visser et al., 2009; Rotics et al., 2017).

On a continental scale, a system for predicting the movement of birds from environmental conditions is important for reducing collisions with buildings, aircraft, wind turbines and other structures (Doren \& Horton, 2018; Gasteren et al., 2018). Bird responses to powerful ground-based artificial light sources at night in urban areas have been studied (Doren et al., 2017; Sorteet et al., 2017; Smallwood \& Bell, 2020). Urbanization increases the likelihood of feed-provided birds reducing their migration activity (Bonnet-Lebrun et al., 2020). The main biological mechanism regulating seasonal variation in migration rate is the seasonal difference in the duration of migration stops. In autumn, birds stay longer in search of 
food, thus taking longer to move to wintering grounds than to move to breeding grounds during spring migration (Schmaljohann, 2018).

During migration, the availability of food that affects the success, nature and timing of bird movements is critical for many species (Drent et al., 2006; Newton, 2006; Vilkov, 2013; Wolfe et al., 2014). Of great importance is the relationship between migration routes and fruit production along the tree-shrub route (Karpov, 2017), including fruit and berries (Tattoni et al., 2019). The availability of quality and accessible food determines where migratory birds stop (McWilliams et al., 2004). Catching migratory birds in the autumn has revealed higher daily body weight gain in areas where fruit was available, compared with individuals taken in areas where fruit and berry plants were not (Thomas, 1979; Bairlein, 2002). The experimental removal of available fruits resulted in a decrease in local autumn migration in these areas (Parrish, 2000). Early ripening mulberries are very popular among birds (Komarov \& Komarova, 2001; Gubin, 2018; Lyakh, 2018). The influence of wood-shrubby plantations on the composition of ornithological fauna in the urban landscape was also proven (Karpov, 2017). The abundance of seasonal fruits is a significant food resource for migratory birds (Petrovich, 2014; Kuzmenko, 2018). By eating fruits, birds carry the seeds of plants, sometimes for considerable distances. Some papers show their role in plant distribution (Koshelev \& Matrukhan, 2010).

In studies of global biodiversity, many bird migration issues remain subject to debate. Many of the factors governing migration flows and migration routes have not been sufficiently explored (Bairlein, 2003). Most birds use different types of plantation for migration. Woodland areas with an appropriate stand structure, undergrowth and scrub layers are very favourable for this purpose, both for camouflage and for supplementary feeding on fruit-bearing plants and feeding in adjacent agrocenoses. The birds' diet is also interesting from the point of view of studying geographical variability in feeding. Consequently, the provision of forest belts with fruit-berry plants and the preservation of the environment along the bird flight path influences their condition and successful migration, which may be crucial for the survival of the population as a whole (Parrish, 1997; Smith et al., 2007; Trierweiler et al., 2014; Oguchi et al., 2017).

The presence of fruit-berry plants, and general climate warming affect bird migration and sedentary population formation (Chaplygina, 2016). Single or group wintering is becoming more and more common amongst such traditional migratory birds as Phoenicurus ochruros (Gmelin, 1774) (Shupova, 2014), Motacilla alba (Linnaeus, 1758) (Chaplygina, 2018), S. vulgaris (Brezgunova, 2013), some species of Fringillidae (Chaplygina, 2018). In anthropogenic landscapes, the proportion of overwintering Corvus frugilegus (Linnaeus, 1758), Turdus pilaris (Linnaeus, 1758) which reduce their nomadic distances is increasing (Chaplygina, 2009; Visser et al., 2009; Shupova, 2014).

Consequently, taking into account the relevance of such studies, we have set an objective: to find out the species diversity of birds feeding in forest belts of different structure, to compare the use of forest belts for feeding on different fruit-berry plants and to evaluate their role in the period of bird migration to places of wintering.

The most widespread berry bearing shrub in the north of the Ukrainian steppe is blackthorn Prunus spinosa Linnaeus, 1753, of the family Rosaceae, which grows mainly in clumps of bushes, often on the edges of the forest, felled areas, usually as dense thickets. Fruits are rounded monostones, similar to plums, with blue waxy patches, $12 \mathrm{~mm}$ in diameter. Fruits contain sugar (levulose and sucrose), malic acid, pectin and tannins, vitamin $\mathrm{C}$, red dyeing agent.

Hawthorn (Crataegus laevigata Poir, 1825), in the investigated region grows in the underbrush of broad-leaved and mixed forests, on the banks of rivers and ravines, in valleys and on the edges. Fruits of $C$. laevigata contain sugars, flavonoids, saponins, phytosterols, carotene, choline, glycosides, tannins, organic acids - malic acid, citric acid, crategusic acid, wine acid, ascorbic acid, etc. Amigdalene and ester oils were found in the seeds.

Elderberry (Sambucus nigra Linnaeus, 1753) has a wide growing area. It is also a species present in the undergrowth of tree plantations. Fruits contain vitamins $\mathrm{C}$ and $\mathrm{E}$, carotene/provitamin $\mathrm{A}$, glucose and fructose (sugar), malic acid and citric acid, ester oil, resins, macro elements ( $\mathrm{Mg}, \mathrm{K}$, $\mathrm{Ca}, \mathrm{Fe}$ ), trace elements ( $\mathrm{Mn}, \mathrm{Cr}, \mathrm{Cu}, \mathrm{Zn}, \mathrm{Co}, \mathrm{Al}, \mathrm{Se}, \mathrm{Ni}, \mathrm{Sr}, \mathrm{Pb}, \mathrm{Br}, \mathrm{I}, \mathrm{Mo}$ ), sambucine, amino acids, dyes, free acids, tyrosine.
Rose eglantine (Rosa canina Linnaeus, 1753) is distributed in the region of study in edge ecotopes, river and ravine banks. Rose eglantine fruits have different shapes: from round to spindle-like. Less than $1 \mathrm{~cm}$ long and more than $3 \mathrm{~cm}$ in diameter, they have a shiny surface covered with wrinkles. Rose eglantine fruits contain large amounts of vitamins, especially vitamin $\mathrm{C}$ (at least $0.2 \%$ ) and vitamins $\mathrm{P}$ and $\mathrm{K}$, flavonoids, carotenoids, tannins, pectins.

The distribution of bird cherry (Prunus padus Linnaeus, 1753) is associated with both tree plantations and open-space biotopes. Fruits are black monostones in the form of a ball, about 8-10 $\mathrm{mm}$ across, taste sweet, sometimes tart and astringent. The smooth berries are of greenish colour, heart-shaped and dense, with time they acquire red and then black colour. They begin to ripen in the middle of June. P. padus fruits contain carbohydrates (fructose, glucose, sucrose), organic acids (malic and citric acids), vitamin $\mathrm{C}$, carotene, cyanogenic compounds, phenolic carboxylic acids and their derivatives, essential oil, nitrogen-containing substances, vitamins $\mathrm{C}, \mathrm{E}$ and $\mathrm{P}$, carotene, flavonoids and phenolic carboxylic acids.

Mountain ash (Sorbus aucuparia Linnaeus, 1753) is distributed in the investigated region both in monotype forest belt plantations and in undergrowth plantations. Fruits contain vitamin $\mathrm{C}$ and carotene, sugar, apple, citric, tartaric and succinic acids, tannins and pectins, sorbitol and sorbosa, amino acids, essential oils, salt, calcium, magnesium and sodium, as well as carotenoids, ascorbic acid, flavonoids, triterpene compounds, bitter substances, sorbic acid.

Purging buckthorn (Rhamnus cathartica Linnaeus, 1753) grows on the slopes of hills and river valleys, as well as in the steppe. The fruits contain anthraglycosides, chrysophanic acid, and alkaloids $-0.17 \%$, sugar.

Representatives of the genus mulberry (Morus) in Ukraine are naturalised in the steppe and forest-steppe zones. Two species are widely spread: Morus alba Linnaeus and M. nigra Linnaeus. The motherland of M. nigra is in South-West Asia, while that of M. alba in East China. It grows on roadsides, field and water protection forests, in artificial forests, on special plantations, on estates, in parks, along streets in cities and villages. The mulberry has been grown as a fruit tree and a forage plant for silkworms for over 4000 years. The tree bears abundant fruit annually, $30-50$, up to $200 \mathrm{~kg}$ of fruit are harvested from one tree. M. nigra is unpretentious to conditions of growth on the territory of Ukraine, to drought and winter frosts, quickly restores crowns after freezing of branches. The life expectancy of $M$. nigra is up to 200, less often 300-500 years. Fruits ripen in late May - August, the period is 2.5-3.0 months. The fruits, or rather the stems, are 2-3 cm long. They are sweet, contain up to $9-11 \%$ sugar, a lot of vitamins, various acids, pectins, trace elements and dyes, as well as resveratrol, which is a strong plant antioxidant. In terms of potassium content, they rank first among berries; healthy and caloric foods not only for humans, but also for wild animals. The seeds of $M$. nigra are very small, 1000 seeds weighing only 1-2 g. Leaves, especially $M$. alba, are the main feed of Bombyx mori (Linnaeus, 1758), larvae of Ourapteryx sambucaria (Linnaeus, 1758), Mimas tiliae (Linnaeus, 1758) and Acronicta aceris (Linnaeus, 1758) also eat them. Many insect species feed on ripe fruits, where they are picked up by birds.

\section{Materials and methods}

The research was carried out in compliance with bioethical standards in accordance with the provisions of the "European Convention for the Protection of Vertebrate Animals used for Experimental and Other Scientific Purposes" (Strasbourg, 1986), and also did not violate the requirements of the "Convention on the Protection of Wild Flora and Fauna and Natural Habitats in Europe" (Berne Convention), the Law of Ukraine "On Animal World", the Law of Ukraine "On Environmental Protection".

This research used bird counts conducted in summer and autumn in forest belts which included fruit and berry bearing plants. In each forest belt 13 counts were made during the period of the greatest ripening of fruit and berry plants (the third decade of May - the third decade of October). The research covered the territory of Kharkov (Kupyansky, Dvurechansky, Borovsk and Shevchenko districts) and Lugansk (Svatovsky district) regions. Routine bird surveys were conducted using generally accepted methods (Ravkin \& Chelintsev, 1990). Multiple mapping was used to record the number of birds feeding on fruits, which allowed for the elimi- 
nation of that part of their population which could be accidentally located near fruit and berry plants. Birds were identified by both voice and visual registration of individuals. All individuals feeding on trees and shrub vegetation and nearby were recorded on the route. Due to the small width of the forest belts it was possible to register all birds. The number of individuals per kilometer of the survey line is expressed as bird numbers. Bird visits to fruit and berry plants were recorded in the morning and evening hours, during the route with a detailed analysis of trees growing in the forest plantations during the ripening of fruits. The route length of 6-7 km was determined in each type of field forest belt. An average of 7.5 hours (5.00-13.00, less often 15.00-20.00), was spent for walking through each line. In winter, birds feeding on fruit and berry plants were not studied in detail due to the lack of sufficient species diversity. The description of fruit-berry plants was based on the characteristic of Blinova et al. (1990).

For average bird abundance, standard deviation and variance were calculated. Some generally accepted ó-diversity indices of biocenoses that express the relationships between the number of species and their density were calculated. To compare the $\alpha$-diversity of bird biocenoses for each research plot the Shannon's, Berger-Parker and Pielou indices were applied (Magurran, 1988).

The investigated forest belts are small in width, most with 3-4 rows ( $20 \mathrm{~m}$, occasionally $30 \mathrm{~m})$, less often $1-2$ rows $(5-10 \mathrm{~m})$. They are mostly old (30-50 years) with different density of plantation: dense (with welldeveloped undergrowth), latticed (with medium-developed undergrowth) and wind-blown (without undergrowth, or with poorly developed undergrowth) and differ in floral composition: Maple-ash wind-blown forest belts (FB1), maple-linden latticed forest belts (FB2), oak- maple-poplar wind-blown forest belts (FB3), oak-maple-linden dense forest belts (FB4). The tiering of the forest bands is weak, but there is a characteristic shrubbery tiering for all types. Undergrowth forms in the dense and latticed forest belts (Table 1). In the investigated forest belts the level of crown closure was determined, in the wind-blown maple-ash and latticed maplelinden forest belts, the index was $0.3-0.4$ or $30-40 \%$, in the wind-blown oak- maple-poplar forest belts $-0.4(40 \%)$. For dense oak-maple-linden forest belts, the crown closure index was $0.5-0.6$ or $(50-60 \%)$.

A comparison of the similarities among the bird biocenoses was performed using cluster analysis with Origin Pro software (One Roundhouse Plaza Origin Lab Corporation Northampton, MA01060, USA, 2015, 64 bit Beta 3 69.2.196).

\section{Results}

In the forest belt of the investigated region, birds feed on the fruits of at least 15 plant species. We have identified the nine main fruit-berry plant species which are the most common feeders of birds during summer movements and migrations. Most of the fruit-berry plants grow in the forest belt in the indigenous tree formations of the region, where they are native species, though some of which are introduced. Some have been planted in the forest belts with major species of trees and shrubs, but many have penetrated through seed zoochory. A total of 6,064 observations of individual birds of 43 species feeding on fruit and berry plants were registered, $81.4 \%$ of which are passerines (Table 2). Conservation status of the studied species: 9 bird species are protected by the Bonn Convention, i.e. U. epops, F. albicollis, F. parva, S. rubetra, and others). 17 species are listed in the Berne Convention (II), namely: M. alba, L. collurio, L. minor, P. major, S. europaea, and others; 18 species are protected by the Berne Convention (P. montanus, F. coelebs, Ch. chloris, E. hortulana, and others). 1 species is listed in the Red Book of Ukraine (C. oenas), 2 species are in Red List of Kharkov region (C. oenas, E. calandra). 6 species have no conservation status. Most of the studied species belong to several protected categories at the same time.

The highest average number of birds feeding in forest belts ( $4.14 \mathrm{ind} / \mathrm{km})$ was recorded in oak and maple-linden dense forest belts, the lowest $(1.48 \mathrm{ind} / \mathrm{km})$ - in maple-ash wind-blown forest belts. In oakmaple-linden and oak-maple-poplar forest belts (both wind-blown and dense), the abundance dispersion is high (4.9 and 5.7, respectively), which indicates a high anthropogenic influence on these habitats. In maple-linden and maple-ash forest belts the dispersion is significantly lower (1.8 and 1.9).

As a result of data processing, the correlation coefficient of the investigated species was determined, which showed a direct correlation between the number of birds feeding on fruit-berry plants in the forest belt and its type. A high correlation coefficient between the number of birds and the type of forest belt (each of which is characterized by certain floral composition and density) was found in 42 species. Among these it is possible to allocate $F$. albicollis (0.98), L. collurio (0.97), C. cornix (0.99), T. pilaris (0.97), O. oriolus (0.97), S. curruca (0.97), and others (Table 2). Based on the data obtained, it can be stated that there is a relationship between bird numbers and forest belt type during migration. The largest number of birds was recorded in oak-maple-linden dense forest belts, which indicates the fact that the specific composition of vegetation and the density of plantations are conditioned, and by no means accidental.

Maple-linden latticed forest belts characterize the best data of the indices in $\alpha$-diversity of birds. The belts have the highest Shannon and Pielou indices with the lowest Berger-Parker indices. In other forest belts $\alpha$-diversity of feeding birds is slightly lower, data on species diversity and distribution evenness of birds in the forest belts are close. Oak-maplelinden dense forest belts are differentiated as showing the strongest pressure of domination (Fig. 1). According to the results of the cluster analysis, bird assemblages feeding in dense oak-maple-linden and wind-blown oak-maple-poplar forest belts differ significantly from those of windblown maple-ash and latticed maple-linden forest belts (Fig. 2).

Juicy fruit during summer-autumn prevailed in the diet of S. vulgaris $11.8 \%$ of the total number of birds observed to feed on this food resource (n = 6064), Ch. chloris - 11.3\%, and also F. coelebs $-9.3 \%, T$. philomelos $-7.3 \%$, C. coccothraustes $-7.1 \%$, T. merula $-5.4 \%$. For the rest of the birds, they were of minor importance and made up less than $5 \%$ of the total diet content. The end of summer - autumn is characterized by the movement of migrants which search for food throughout their journey, thus establishing transport and trophic interaction with local bird populations. Average feeding rates for the 6 most frequently observed species ranged from 1.3 to 2.0 fruits $/ \mathrm{min}$. We recorded 325 aggressive interactions, of which $55 \%$ were intraspecific. Depending on the type of fruit tree, 12-42 species of birds use its fruit for feeding. Birds most actively consumed S. nigra, M. nigra, R. cathartica, P. padus berries.

Table 1

Composition of different types of forest belts in plant species and tiers

\begin{tabular}{|c|c|c|c|c|}
\hline Types of forest belts & I tier & II tier & Undergrowth & Shrub layer \\
\hline $\begin{array}{l}\text { Maple-ash wind-blown } \\
\text { forest belts (FB1) }\end{array}$ & $\begin{array}{l}\text { Fraxinus excelsior } \\
\text { Linnaeus, } 1753-60 \%\end{array}$ & Acer platanoides Linnaeus, $1753-20 \%$ & No underbrush & $\begin{array}{l}\text { Prunus spinosa Linnaeus, } 1753-5 \% \text {, } \\
\text { C. laevigata Poir, } 1825-10 \% \text {, Sambucus } \\
\text { nigra Linnaeus, } 1753-5 \%\end{array}$ \\
\hline $\begin{array}{l}\text { Maple-linden latticed } \\
\text { forest belts (FB2) }\end{array}$ & $\begin{array}{l}\text { A. platanoides Linnaeus, } 1753- \\
30 \% \text {, Tilia cordata Mill, } 1768-20 \%\end{array}$ & Without the II tier & $\begin{array}{l}\text { Crataegus laevigata } \\
\text { Poir. (DC.) }-10 \%\end{array}$ & $\begin{array}{l}\text { Prunus spinosa Linnaeus, } 1753-20 \% \text {, } \\
\text { S. nigra Linnaeus, } 1753-20 \%\end{array}$ \\
\hline $\begin{array}{l}\text { Oak-maple-poplar wind- } \\
\text { blown forest belts (FB3) }\end{array}$ & $\begin{array}{l}\text { Quercus robur Linnaeus, } 1753 \text { - } \\
30 \%\end{array}$ & $\begin{array}{l}\text { Acer platanoides Linnaeus, } 1753-20 \% \text {, } \\
\text { Morus nigra Linnaeus, } 1753-10 \% \text {, } \\
\text { Populus alba Linnaeus, } 1753-10 \%\end{array}$ & No underbrush & $\begin{array}{l}\text { C. laevigata Poir, } 1825-15 \% \text {, } \\
\text { Rosa canina Linnaeus, } 1753-15 \%\end{array}$ \\
\hline $\begin{array}{l}\text { Oak-maple-linden dense } \\
\text { forest belts (FB4) }\end{array}$ & $\begin{array}{l}\text { Q. robur Linnaeus, } 1753-20 \% \text {, } \\
\text { Acer negundo Linnaeus, } 1753- \\
20 \% \text {, Acer tataricum Linnaeus, } \\
1753)-10 \% \text {, Tilia cordata Mill, } \\
1768-10 \%\end{array}$ & $\begin{array}{l}\text { A. platanoides Linnaeus, } 1753-5 \% \text {, Ulmus } \\
\text { laevis Pallas-5\%, Sorbus aucuparia Lin- } \\
\text { naeus, } 1753-4 \% \text {, Morus nigra Linnaeus- } \\
3 \% \text {, Prunus cerasus Linnaeus-2\%,P. } \\
\text { padus Linnaeus, } 1753-3 \%\end{array}$ & $\begin{array}{l}\text { C. laevigata-2\%, } \\
\text { Rhamnus cathartica } \\
\text { Linnaeus, } 1753-1 \%\end{array}$ & $\begin{array}{l}\text { R. canina Linnaeus, } 1753-5 \% \text {, Prunus } \\
\text { spinosa Linnaeus, } 1753-5 \% \text {, P. cerasus } \\
\text { Linnaeus, } 1753-3 \% \text {, Sambucus nigra } \\
\text { Linnaeus, } 1753-2 \%\end{array}$ \\
\hline
\end{tabular}

Note: * - the ratio of plants in the species composition of the forest belt (\%). 
Table 2

Distribution of birds in different types of forest belts by numbers* (ind./km; $\mathrm{n}=13 ; \mathrm{x} \pm \mathrm{SE}$ )

\begin{tabular}{|c|c|c|c|c|c|}
\hline \multirow[b]{2}{*}{ Order } & \multirow[b]{2}{*}{ Species name } & \multicolumn{4}{|c|}{ Forest belts type } \\
\hline & & $\begin{array}{l}\text { maple-ash wind-blown } \\
\text { forest belts (FB1) }\end{array}$ & $\begin{array}{l}\text { maple-linden latticed } \\
\text { forest belts (FB2) }\end{array}$ & $\begin{array}{l}\text { oak-maple-linden dense } \\
\text { forest belts (FB3) }\end{array}$ & $\begin{array}{l}\text { oak-maple-poplar wind- } \\
\text { blown forest belts (FB4) }\end{array}$ \\
\hline \multirow{3}{*}{ Columbiformes } & Columba palumbus (Linnaeus, 1758) & $0.92 \pm 0.57$ & $1.23 \pm 0.71$ & $0.92 \pm 0.99$ & $2.15 \pm 0.65$ \\
\hline & C. oenas (Linnaeus, 1758) & $0.31 \pm 0.43$ & $0.77 \pm 0.83$ & $0.54 \pm 0.66$ & $1.15 \pm 0.78$ \\
\hline & Streptopelia turtur (Linnaeus, 1758) & $0.31 \pm 0.43$ & $0.77 \pm 0.95$ & $0.31 \pm 0.43$ & $2.23 \pm 0.66$ \\
\hline Upupiformes & Upupa ерорs (Linnaeus, 1758) & $0.15 \pm 0.26$ & $0.38 \pm 0.53$ & $0.46 \pm 0.64$ & $0.62 \pm 0.66$ \\
\hline \multirow{4}{*}{ Piciformes } & Jynx torquilla (Linnaeus, 1758) & $0.15 \pm 0.26$ & $0.38 \pm 0.47$ & $0.53 \pm 0.75$ & $1.23 \pm 0.98$ \\
\hline & Picus canus (Gmelin, 1788) & $0.53 \pm 0.50$ & $0.77 \pm 0.71$ & $0.23 \pm 0.36$ & $0.46 \pm 0.50$ \\
\hline & Dendrocopos major (Linnaeus, 1758) & $0.92 \pm 0.43$ & $0.92 \pm 0.42$ & $2.15 \pm 0.96$ & $2.38 \pm 0.78$ \\
\hline & D. minor (Linnaeus, 1758) & $0.38 \pm 0.47$ & $1.00 \pm 0.76$ & $0.15 \pm 0.26$ & $0.31 \pm 0.43$ \\
\hline \multirow{35}{*}{ Passeriformes } & Anthus campestris (Linnaeus, 1758) & $1.15 \pm 0.96$ & $1.61 \pm 0.99$ & $1.38 \pm 1.18$ & $1.38 \pm 1.18$ \\
\hline & Motacilla alba (Linnaeus, 1758) & $0.53 \pm 0.50$ & $0.54 \pm 0.50$ & $2.15 \pm 1.57$ & $2.77 \pm 1.75$ \\
\hline & Lanius collurio (Linnaeus, 1758) & $1.38 \pm 1.07$ & $1.85 \pm 1.70$ & $4.23 \pm 3.98$ & $5.38 \pm 4.05$ \\
\hline & L. minor (Gmelin, 1788) & $0.53 \pm 0.50$ & $1.62 \pm 1.99$ & $1.31 \pm 0.99$ & $1.31 \pm 1.30$ \\
\hline & Oriolus oriolus (Linnaeus, 1758) & $1.92 \pm 2.07$ & $1.08 \pm 1.66$ & $3.54 \pm 3.74$ & $2.23 \pm 2.47$ \\
\hline & Sturnus vulgaris (Linnaeus, 1758) & $3.84 \pm 2.01$ & $4.62 \pm 2.11$ & $19.38 \pm 5.99$ & $27.62 \pm 5.24$ \\
\hline & Garrulus glandarius (Linnaeus, 1758) & $1.07 \pm 0.72$ & $2.31 \pm 0.47$ & $0.77 \pm 0.48$ & $1.31 \pm 0.53$ \\
\hline & Pica pica (Linnaeus, 1758) & $0.15 \pm 0.26$ & $0.38 \pm 0.59$ & $0.15 \pm 0.26$ & $0.23 \pm 0.36$ \\
\hline & Corvus cornix (Linnaeus, 1758) & $1.31 \pm 0.53$ & $2.23 \pm 0.63$ & $0.84 \pm 0.65$ & $1.69 \pm 0.90$ \\
\hline & Hippolais icterina (Vieillot, 1817) & $0.00 \pm 0.00$ & $0.08 \pm 1.14$ & $0.38 \pm 0.47$ & $0.54 \pm 0.66$ \\
\hline & Sylvia nisoria (Bechstein, 1795) & $0.38 \pm 0.53$ & $2.31 \pm 2.53$ & $2.30 \pm 2.73$ & $3.69 \pm 3.62$ \\
\hline & S. atricapilla (Linnaeus, 1758) & $1.08 \pm 0.85$ & $2.62 \pm 2.01$ & $7.61 \pm 5.95$ & $7.08 \pm 4.85$ \\
\hline & S. borin (Boddaert, 1783) & $0.38 \pm 0.53$ & $0.69 \pm 0.85$ & $0.46 \pm 0.64$ & $0.46 \pm 0.64$ \\
\hline & S. communis (Latham, 1787) & $0.46 \pm 0.50$ & $1.15 \pm 1.27$ & $2.08 \pm 1.63$ & $2.15 \pm 1.57$ \\
\hline & S. curruca (Linnaeus, 1758) & $0.23 \pm 0.36$ & $0.46 \pm 0.64$ & $0.31 \pm 0.43$ & $0.38 \pm 0.47$ \\
\hline & Ficedula albicollis (Temminck, 1815) & $0.09 \pm 0.13$ & $0.62 \pm 0.95$ & $3.15 \pm 3.91$ & $2.38 \pm 2.99$ \\
\hline & F. parva (Bechstein, 1794) & $0.08 \pm 0.14$ & $0.15 \pm 0.28$ & $0.23 \pm 0.36$ & $0.15 \pm 0.26$ \\
\hline & Saxicola rubetra (Linnaeus, 1758) & $0.77 \pm 0.71$ & $0.85 \pm 0.78$ & $1.08 \pm 0.88$ & $0.85 \pm 0.65$ \\
\hline & Erithacus rubecula (Linnaeus, 1758) & $1.85 \pm 0.52$ & $1.85 \pm 0.85$ & $6.84 \pm 2.83$ & $7.54 \pm 3.10$ \\
\hline & Luscinia luscinia (Linnaeus, 1758) & $0.69 \pm 0.75$ & $0.46 \pm 0.57$ & $1.53 \pm 1.43$ & $1.54 \pm 1.59$ \\
\hline & Turdus pilaris (Linnaeus, 1758) & $2.31 \pm 2.63$ & $2.69 \pm 3.37$ & $4.31 \pm 4.27$ & $5.76 \pm 4.64$ \\
\hline & T. merula (Linnaeus, 1758) & $1.31 \pm 1.09$ & $2.54 \pm 1.20$ & $10.23 \pm 2.40$ & $10.46 \pm 2.96$ \\
\hline & T. philomelos (C. L. Brehm, 1831) & $3.31 \pm 1.36$ & $3.62 \pm 1.40$ & $13.69 \pm 6.13$ & $13.76 \pm 6.37$ \\
\hline & Parus caeruleus (Linnaeus, 1758) & $0.61 \pm 0.47$ & $0.62 \pm 0.47$ & $0.62 \pm 0.47$ & $0.77 \pm 0.47$ \\
\hline & P. major (Linnaeus, 1758) & $1.31 \pm 0.69$ & $2.15 \pm 1.31$ & $2.15 \pm 0.80$ & $3.15 \pm 1.62$ \\
\hline & Sitta europaea (Linnaeus, 1758) & $0.46 \pm 0.50$ & $0.38 \pm 0.47$ & $0.84 \pm 0.52$ & $0.85 \pm 0.52$ \\
\hline & Passer domesticus (Linnaeus, 1758) & $0.69 \pm 0.64$ & $0.92 \pm 1.14$ & $0.92 \pm 0.85$ & $0.85 \pm 0.78$ \\
\hline & P. montanus (Linnaeus, 1758) & $3.00 \pm 1.38$ & $3.23 \pm 1.63$ & $4.07 \pm 1.93$ & $5.23 \pm 3.09$ \\
\hline & Fringilla coelebs (Linnaeus, 1758) & $6.53 \pm 1.88$ & $4.38 \pm 1.02$ & $16.15 \pm 6.91$ & $16.92 \pm 6.22$ \\
\hline & Chloris chloris (Linnaeus, 1758) & $7.53 \pm 1.81$ & $7.54 \pm 1.81$ & $18.69 \pm 4.02$ & $18.69 \pm 3.51$ \\
\hline & Carduelis carduelis (Linnaeus, 1758) & $1.77 \pm 0.63$ & $1.46 \pm 0.97$ & $1.84 \pm 0.67$ & $2.54 \pm 1.43$ \\
\hline & Coccothraustes coccothraustes (Linnaeus, 1758) & $8.31 \pm 2.85$ & $8.38 \pm 2.66$ & $6.85 \pm 1.60$ & $9.62 \pm 2.17$ \\
\hline & Emberiza calandra (Linnaeus, 1758) & $0.15 \pm 0.26$ & $0.23 \pm 0.36$ & $0.31 \pm 0.43$ & $0.85 \pm 1.17$ \\
\hline & E. citrinella (Linnaeus, 1758) & $1.23 \pm 0.59$ & $1.31 \pm 0.64$ & $2.62 \pm 0.66$ & $2.46 \pm 0.73$ \\
\hline & E. hortulana (Linnaeus, 1758) & $1.92 \pm 0.58$ & $2.08 \pm 0.30$ & $3.69 \pm 1.98$ & $4.69 \pm 2.75$ \\
\hline
\end{tabular}

Note: * average absolute number of birds that fed on juicy fruits of plants growing in forest belts of different types in the northern steppe zone of Ukraine.
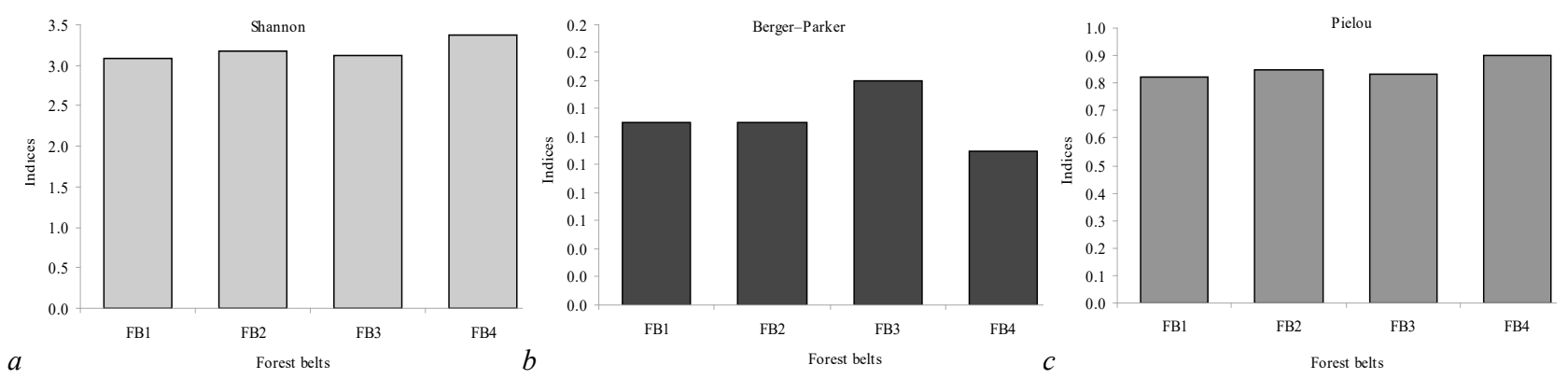

Fig. 1. $\alpha$-Diversity of birds in forest belts of different types that have fruit-bearing berry plants Kharkiv and Lugansk regions $(\mathrm{n}=13)$

The smallest number of bird species was noted to feed on $P$. spinosa, R. canina, S. aucuparia fruit. Significant differences in the species composition of feeding birds on different fruit plants are associated with differences in the Shannon index data for trophic consortia of fruit trees (Fig. 3). Uniformity of birds' distribution on all fruit trees is high. The differences between the Berger-Parker and Pielou index data for feeding bird assemblages on different fruit trees are not significant. In cluster analysis, the number of feeding bird species was a more influential factor in dividing assemblages into similarity groups than data from ó-diversity indices.
The consortium of S. nigra and M. nigra is divided in one flank of the dendrogram and the small numbered-species assemblages of $P$. spinosa, $R$. sapipa and S. aucuparia - on the opposite flank (Fig. 4). The central block of the dendrogram occupies a block of two pairs of trophic consortium assemblages: $P$. spinosa $-P$. cerasus and $R$. cathartica $-P$. padus. The main one in bird nutrition is $S$. racemosa. Representatives of 39 species of birds were observed to feed on its berries. The main consumers of its fruits are Ch. chloris (11.6\% of the total number of birds observed to feed on this fruit; $\mathrm{n}=947), S$. vulgaris $(11.2 \%)$, F. coelebs $(10.0 \%)$, 
S. atricapilla (8.2\%), E. rubecula (7.7\%), T. philomelos (5.1\%) and others $(0.3-4.5 \%)$. Since the ripening of $M$. nigra fruit (early June), they became the main supplement to the diet of 42 bird species adults and chicks (Fig. 5).

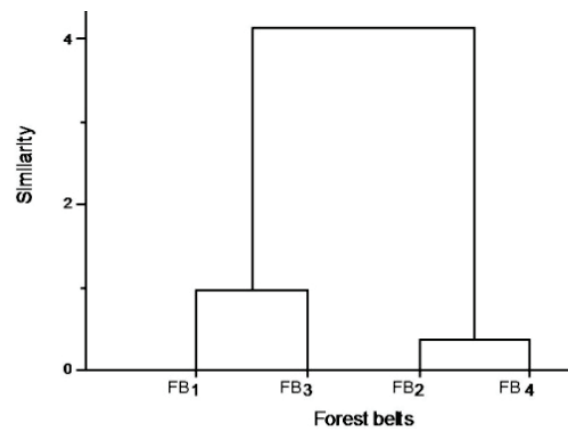

Fig. 2. The similarity of bird communities in forest belts of different types that have fruit-bearing berry plants Kharkiv and Lugansk regions


Fig. 3. ó-Diversity of birds on fruit trees (in decreasing order of frequency of occurrence of birds on fruit plants): 1 -Sambucus nigra, 2-Morus nigra, 3-Prunus spinosa, 4-Crataegus laevigata, 5-Rosa canina,

6-Rhammus cathartica, 7-Sorbus aucuparia, 8-Prunus padus, 9-Prunus cerasus

Its fructification season lasts for 3.0-3.5 months, which provides berries to most nesting and nomadic birds. M. nigra berries were most frequently consumed by $S$. vulgaris $(24.5 \%$ of the total number of birds observed to feed on this fruit; $\mathrm{n}=922), C h$. chloris $(14.8 \%), F$. coelebs (14.6\%), C. coccothraustes (10.3\%), T. philomelos (10.1\%), T. merula
(7.3\%) and E. rubecula (7.3\%), P. montanus (6.1\%), S. atricapilla (5.7\%), and others $(0.2-4.1 \%)$.

The fruit of $R$. cathartica attracted 32 bird species. The dominant species were Ch. chloris $(10.6 \%$ of the total number of birds observed to feed on this fruit; $\mathrm{n}=548), F$. coelebs $(10.2 \%)$, T. philomelos $(8.4 \%)$, S. vulgaris (6.4\%), E. rubecula (5.8), P. major (5.1\%), and others (0.4 4.9). There were 30 bird species registered on $P$. padus fruit-bearing trees. Ch. chloris (11.8\% of the total number of birds observed to feed on this fruit; $\mathrm{n}=629)$, F. coelebs (9.7\%), S. atricapilla (8.6\%), S. vulgaris $(7.3 \%)$, T. philomelos (6.8\%), L. collurio (6.7\%), P. major (6.5\%), T. merula (5.9\%), S. nisoria $(5.2 \%)$, and others $(0.2-4.9 \%)$ were registered. Twenty-eight bird species were observed to feed on C. laevigata, of which the following were dominant: C. coccothraustes $(14.3 \%$ of the total number of birds observed to feed on this fruit; $\mathrm{n}=554), F$. coelebs $(13.7 \%)$, Ch. chloris $(12.3 \%)$, S. vulgaris $(11.2 \%)$, L. collurio $(6.9 \%)$, T. philomelos $(6.1 \%)$, and others $(0.2-4.5 \%)$. The participation of $P$. cerasus in forest belt formation is insignificant; it mainly enters this biotope from cultural plantations, due to ornithochory. Cherry fruit attracted 25 species of birds from the forest belt as well as adjacent biotopes. Its fruit were primarily the food of $C$. coccothraustes $(20.7 \%$ of the total number of birds observed to feed on this fruit; $\mathrm{n}=752)$, Ch. chloris $(12.5 \%), S$. vulgaris $(11.2 \%)$ and $T$. philomelos (11.0\%), in lesser degree - of $F$. coelebs (6.5\%), T. merula (5.6\%), O. oriolus $(5.1 \%)$, and others $(0.1-4.0 \%)$. S. aucuparia berries served as the food of 14 species of birds, mainly $T$. pilaris $(20.1 \%$ of the total number of birds observed to feed on this fruit; $\mathrm{n}=488), S$. vulgaris (17.6\%), Ch. chloris (15.8\%), T. philomelos (11.5\%), P. montanus (7.6\%), F. coelebs (7.0\%), T. merula (6.4\%), C. coccothraustes (5.5\%), and others $(0.4-4.3 \%)$. P. spinosa berries were consumed by 13 species of birds, among which the most frequent were $S$. vulgaris $(18.7 \%$ of the total number of birds observed to feed on this fruit; $\mathrm{n}=225), C$. coccothraustes $(17.3 \%)$ and $T$. merula $(11.1 \%)$, as well as $F$. coelebs $(9.7 \%), T$. pilaris (8.9\%), Ch. chloris $(8.4 \%), D$. major $(8.0 \%), P$. canus $(5.3 \%)$ and $T$. philomelos $(5.3 \%)$, others ( $0.9-3.1 \%)$. R. canina berries were consumed by 13 bird species in late autumn and winter. Ch. chloris $(15.6 \%$ of the total number of birds observed to feed on this fruit; $\mathrm{n}=294), F$. coelebs (12.3\%), T. merula (12.2\%), T. pilaris (11.6\%), P. montanus (11.6\%), T. philomelos (10.9\%), S. vulgaris (8.8\%), and others (1.0-3.4\%) were registered.

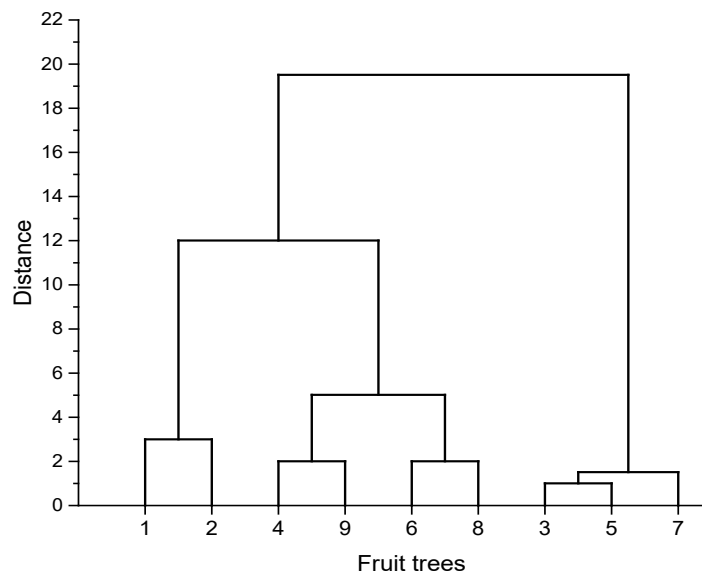

Fig. 4. The similarity of bird assemblages on fruit trees (in decreasing order of frequency of occurrence of birds on fruit plants): 1 - Sambucus nigra, 2-Morus nigra, 3-Prunus spinosa, 4-Crataegus laevigata, 5-Rosa canina, 6-Rhamnus cathartica, 7-Sorbus aucuparia, 8 -Prunus padus, 9-Prumus cerasus

Slightly more than half $(51.2 \%)$ of the species composition of birds feeding on fruit and berry plants belongs to migratory birds, the share of sedentary birds is $27.9 \%$, nomadic birds $-20.9 \%(n=43)$. Therefore, about half of the species use forage resources of the forest belt in the northern steppe zone of Ukraine all year round. In the list of plants, P. spinosa, $R$. canina and $S$. aucuparia were most actively used by sedentary and nomadic species (Fig. 6). The use of these plants by migratory species was minimal (14.3-15.4\%). In contrast, the proportion of migratory birds using $R$. cathartica and $P$. padus is significant, $59.4 \%$ and $60.0 \%$, respectively. As 
we see, the distribution of ornithofauna of fruit-berry plants by these indicators corresponds to the two last blocks of the cluster analysis dendrogram. The role of other plants ( . nigra, $M$. nigra, $C$. laevigata, $P$. cerasus) can be considered equal for both sedentary and migratory bird species.

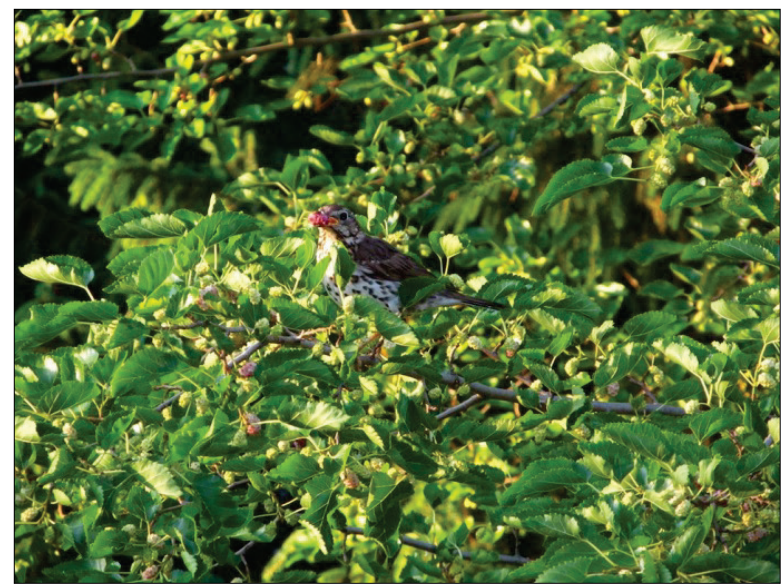

Fig. 5. The song thrush (T. philomelos) feeds on mulberry fruit. Photo by Y. V. Bengus

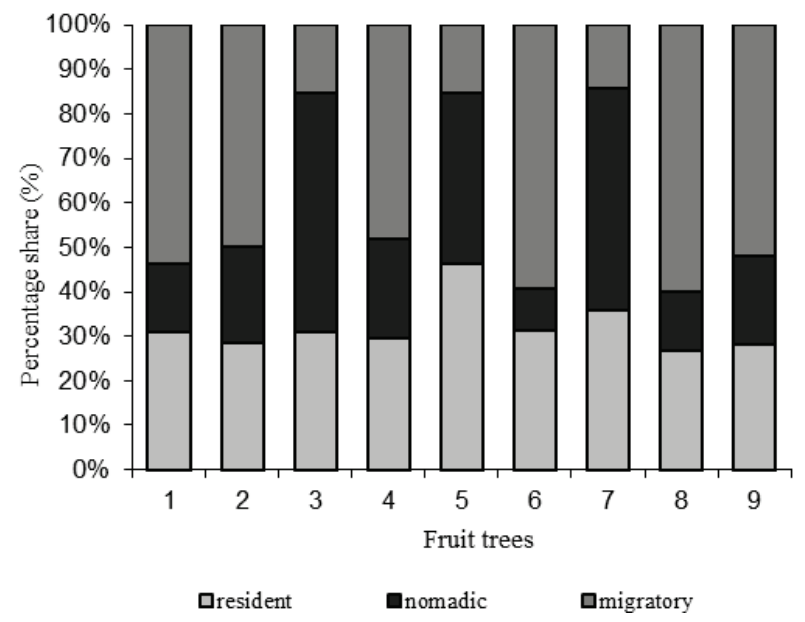

Fig. 6. Distribution of birds of different settlement status on fruit trees by number (in decreasing order of occurrence of birds on fruit plants):

1-Sambucus nigra, 2-Morus nigra, 3-Prunus spinosa, 4-Crataegus laevigata, 5-Rosa canina, 6-Rhamnus cathartica, 7-Sorbus aucuparia, 8-Prunus padus, 9-Prunus cerasus

\section{Discussion}

During migration, birds learn to avoid local competition and to reach areas with better access to resources while minimizing travel distances within the constraints imposed by the geographical location of each species (Somveille et al., 2019). Autumn migration of birds is accompanied by stopovers during which they accumulate energy resources (Schmaljohann, 2018). The presence of fruit and berry plants in forest belts of different types provides an opportunity for birds to find food during the summer-autumn and winter periods (Schmaljohann, 2018). All this makes forest belts attractive to birds. The a priori fact is that plant food, including juicy fruits, in the nesting period for most birds is secondary or accidental. According to our previous studies, chicks of the first breeding cycle, i.e. S. atricapilla (Chaplygina, 2016), F. albicollis (Chaplygina et al., 2015), E. rubecula (Chaplygina et al., 2016), M. striata (Chaplygina et al., 2016; 2018), T. philomelos (Chaplygina \& Savynskay, 2016), F. coelebs (Chaplygina, 2018), and representatives of the genus Phoenicurus, and other species (Prokofieva, 2005) receive mainly animal food from parents. In spite of this, the fruits are the main food of most birds and their chicks from those we have observed. The diet of late broods of the same species may, in addition to invertebrates, consist of various berries. It is also believed that berry yields often determine fluctuations in the numbers of many birds (Newton, 2006).
Scientists repeatedly point to the abundance of seasonal fruit as a significant food resource for migratory birds, which can improve fat reserves and immunity during stopovers (Petrovich, 2014; Kuzmenko, 2018). By eating fruit, birds spread plant seeds, sometimes over considerable distances. Some papers have shown the role of birds in plant distribution (Koshelev \& Matrukhan, 2010). Consequently, the role that succulent fruit play in the life of birds in forest belts should not be underestimated. We have registered 43 species of birds feeding on fruit and berry plants. This is $80 \%$ of the recorded species of birds in the forest belts (Pisotska, 2018). No bird species has a predilection for a particular fruit. According to literature data, 16 bird species feed on $S$. racemosa (Prokofieva, 2005), the main ones being Turdus species, P. major, P. caeruleus, S. vulgaris, $P$. domesticus, Ch. chloris and B. garrulus (Olney, 1966).

$M$. nigra is very popular among birds and its fruit are eaten by adults and fed to their chicks such as Streptopelia senegalensis (Linnaeus, 1766), Acridotheres tristis (Linnaeus, 1766) (Gubin, 2018), T. merula (Komarov, \& Komarova, 2001) and C. palumbus (Lyakh, 2018). During the summer fruiting season of $M$. nigra, birds are also actively involved in eating invertebrates on its fruit (M. striata, F. albicollis, M. alba, Sylvia species and others). According to observations made by Koshelev (2015), 62 species of forest birds eat the fruit of M. nigra. Fruit of Prunus avium (Linnaeus, 1755) are eaten in large quantities by G. glandarius, various species of Turdus, F. coelebs and Pinicola enucleator (Linnaeus, 1758) (Turcek, 1968). S. aucuparia berries are used by 9 bird species in the Leningrad Region, among which Corvidae was the dominant bird family (Prokofieva, 2005). The eating of juicy fruit was registered for all Piciformes in the Leningrad Region (Bardin \& Tarasenko, 2018). Dryocopus martius (Linnaeus, 1758) picks berries of Sorbus aucuparia subsp. sibirica ((Hedl.), Krylov, 1933) (Berezovikov, \& Isachenko, 2018), Malus baccata (Linnaeus), Borkh, 1803) (Lyapunov et al., 2017; Feldman \& Berezovikov, 2017) and $C$. laevigata (Vasilevskaya, 2018).

The famously stenophagous white-backed woodpecker Dendrocopos leucotos (Bechstein, 1802), all year round extracts xylophagous insects (Malchevsky \& Pukinsky, 1983). However, in the Far East, individuals of the form of D. leucotos sinicus (Buturlin, 1907) have plant food as the staple of the diet during autumn and winter (fruit of Phellodendron amurense (Rupr, 1857), Kalopanax septemlobus (Thunb) (Koidz, 1925), and Juglans mandshurica (Maxim, 1856) (Polivanov, 1981). Birds do not specialize in the extraction of fruit of a certain species, but feed on different ones. Thus, in the diet of $S$. vulgaris, T. philomelos, T. merula, Ch. chloris and F. coelebs we found the fruit of all 9 studied plant species. Prokofieva (2001a) observing 5 species of Turdus, noted that only T. philomelos fed on Vaccínium myrtillus berries (Linnaeus, 1758) composing 16.3\% out of its all food objects. According to her data, S. europaea fed on V. myrtillus and Fragaria vesca berries (Linnaeus, 1753) (Prokofieva, 2001b). G. glandarius used berries of S. nigra, S. aucuparia and Vaccinium subgen (Gray, 1848), Oxycoccus palustris (Gray, 1848). In August remains of Sambucus racemosa berries were found in droppings of Corvidae flock birds composed of C. cornix, C. frugilegus and Corvus monedula (Linnaeus, 1758). In September droppings of this flock contained stones of Cornus suecica (Linnaeus, 1753) (Prokofieva, 2001b, 2002, 2003). The fruit are also eaten by birds when there is a lack of typical food. Often in cold and windy weather insect eaters such as Ficedula, Muscicapa, Motacilla, Saxicola, Parus, and others, especially actively feed on berries. Similar behaviour is also known for Aegithalos caudatus (Linnaeus, 1758) (Croq, 2003).

For feeding birds, the structure of the forest belt is also important. Pereira et al. (2014) have shown that insectivorous birds were more numerous in dense oak plantations with a wider undergrowth vegetation cover. Insectivores, partly due to the lack of suitable nest sites, may also face food shortages that limit their distribution (Pereira et al., 2014). Trunk foraging species and birds in agro-forest open habitats increased their abundance in cleared areas and remained less frequent in denser forests (Shirihai et al., 2001). However, the density of Piciformes and Passeriformes that feed on the trunks during wood thinning falls from 56.2 to 28.0 pairs $/ \mathrm{km}$. Nevertheless, if the woody vegetation is thick enough, the clearing of the vegetation may have little impact on birds. If thinning is accompanied by selective tree clearing, the combined effect of these two factors on the bird assemblage is more intense (Shirihai et al., 2001; Blinkova \& Shupova, 2018). This management practice reduces the number of undergrowth bird species, but thinning also 
causes changes in the composition of birds of the tree canopy and benefits other species associated with open agroforestry habitats (Shirihai et al., 2001). For the north of the steppe zone of Ukraine, our analysis of $\alpha$ diversity revealed that latticed forest belts were the most attractive for birds. The similarity of bird assemblages to each other was more influenced by the number of main tree species of the forest belt than by its structure.

\section{Conclusion}

The presence of fruit-berry plants in woodlands of various types enables birds to find additional food both in summer-autumn, and in winter. In the conditions of the north of the steppe zone of Ukraine 43 bird species of four orders, $81.4 \%$ of which are Passeriformes, were observed to feed on the fruit of plants of field-protective woodlands. Birds most actively visit dense oak-maple-linden forest belts, least actively wind-blown maple-ash forest belts. The best characteristics of $\alpha$-diversity of ornithofauna are recorded for latticed maple-linden forest belts: Shannon (3.37) and Pielou (0.90) data are the highest, Berger-Parker (0.11) data are the lowest. The similarity of bird assemblages of trophic consortia is influenced more by the number of main tree species of the forest belt than by its structure. In the summer-autumn diet juicy fruit were most important for $S$. vulgaris (11.8\% of the total number of birds observed to feed on this food resource; $\mathrm{n}=6064)$, Ch. chloris $(11.3 \%)$, F. coelebs $(9.3 \%)$, T. philomelos $(7.3 \%)$, C. coccothraustes $(7.1 \%)$, T. merula (5.4\%). For other birds, the share of fruit in the diet was less than $5.0 \%$. Most actively, birds fed on $M$. nigra, $S$. nigra, R. cathartica, P. padus. The highest magnitudes of Shannon index (3.30) of trophic consortia are typical for $M$. nigra, which is used by the largest number of bird species -42 . About a half $(51.2 \%)$ of the species composition of birds feeding on fruit-berry plants were migratory birds. The rest of the birds use forage resources in the forest belts of the northern steppe zone of Ukraine all the year round. P. spinosa, $R$. canina and $S$. aucuparia were most actively used by sedentary and nomadic species, and their use by migratory species is $14.3-15.4 \%$. In contrast, the proportion of migratory birds consuming $R$. cathartica and $P$. padus was $59.4 \%$ and $60.0 \%$, respectively.

The issues of bird migration in many respects, in spite of being extensively studied, remain controversial. The factors that influence migration routes are not well understood. During migration, birds use various types of tree cover, a special place is occupied by forest belts with a certain vegetation composition and structure of the stand for feeding and resting.

\section{References}

Aurbach, A., Schmid, B., Liechti, F., Chokani, N., \& Abhari, R. (2020). Simulation of broad front bird migration across Western Europe. Ecological Modelling, 415,108879

Bairlein, F. (2002). How to get fat: Nutritional mechanisms of seasonal fat accumulation in migratory songbirds. The Science of Nature, 89(1), 1-10.

Bairlein, F. (2003). The study of bird migrations - some future perspectives. Bird Study, 50(3), 243-253.

Bardin, A. V., \& Tarasenko, I. R. (2018). Specifika ekspluatacionnoj troficheskoj konkurencii sinantropnyh i dikih vidov ptic $\mathrm{v}$ antropogennyh landshaftah [Peculiarities of exploitative trophic competition of synanthropic and wild species of birds in anthropogenic landscapes]. Russian Journal of Ecology, 27(1777), 2518-2524 (in Russian).

Bauer, S., \& Hoye, B. J. (2014). Migratory animals couple biodiversity and ecosystem functioning worldwide. Science, 344(6179), 1300-1310.

Berezovikov, N. N., \& Isachenko, A. D. (2018). Zhelna Dryocopus martius kormitsya plodami ryabiny [Zhelna Dryocopus martius feeds on rowan fruits]. Russian Journal of Ecology, 27(1671), 46844685 (in Russian).

Blinkova, O., \& Shupova, T. (2018). Bird communities and vegetation composition in natural and semi-natural forests of megalopolis: Correlations and comparisons of diversity indices (Kyiv city, Ukraine). Ekológia (Bratislava), 37(3), 259-288.

Bonnet-Lebrun, A., Manica, A., \& Rodrigues, A. (2020). Effects of urbanization on bird migration. Biological Conservation, 244, 1-9.

Brezgunova, O. A. (2013). Nochevki skvorcov (Sturnus vulgaris) na zimovkah v g. Harkove [Overnight stays of starlings (Sturnus vulgaris) wintering in Kharkov]. Branta, 16, 120-126 (in Russian).

Chaplygina, A. B. (2009). Osoblyvosti roztashuvannya gnizd drozdiv rodu Turdus v transformovanyh landshaftah Pivnichno-Shidnoyi Ukrayini [Characteristics of nest locations of thrushes of the genus Turdus in transformed landscapes of North-Eastern Ukraine]. Berkut, 18, 135-142 (in Ukrainian).
Chaplygina, A. B. (2016). The consortial relations of eurasian blackcap (Sylvia atricapilla L.) in the forest cenoses of Left bank Ukraine. Studia Biologica, 10(1), 99-110.

Chaplygina, A. B. (2018). Dendrofil'nye vorob'inoobraznyye (Passeriformes) kak strukturno-funktsional'nyj element antropogenno transformirovannykh lesnykh biogeotsenozov Severo-Vostochnoy Ukrainy [Dendrophilic passerines (Passeriformes) as a structural-functional element of anthropogenically transformed forest biogeocoenoses of North-Eastern Ukraine]. Oles Honchar Dnipro National University, Dnipro (in Ukrainian).

Chaplygina, A. B., \& Savinskaya, N. O. (2016). Sovremennoe sostoyanie ornitofauny transformirovannyh landshaftov Severo-Vostochnoy Ukrainy na primere Muscicapidae i Turdidae [Current status of the avifauna of transformed landscapes of North-Eastern Ukraine by the example of Muscicapidae and Turdidae]. Russian Journal of Ecology, 25, 615-647 (in Russian).

Chaplygina, A. B., Savynska, N. O., \& Brygadyrenko, V. V. (2018). Trophic links of the spotted flycatcher, Muscicapa striata, in transformed forest ecosystems of North-Eastern Ukraine. Baltic Forestry, 24(2), 304-312.

Chaplygina, A. B., Yuzyk, D. I., \& Savynskay, H. O. (2016). The robin, Erithacus rubecula (Passeriformes, Turdidae), as a component of autotrophic consortia of forest cenoses, Northeast Ukraine. Vestnik Zoologii, 50(4), 369-378.

Chevallier, D., Handrich, Y., Georges, J., Baillon, F., Brossault, P., Aurouet, A., Maho, Y., \& Massemin, S. (2010). Influence of weather conditions on the flight of migrating black storks. Proceedings of the Royal Society B: Biological Sciences, 277(1695), 2755-2764.

Croq, C. (2003). Notes sur la frugivoree choz la Mésange à longue quene Aegithalos caudatus. Camparaison avec la frugivorus ches divers Paridés [Notes on the frugivoree choz the long-tailed tit Aegithalos caudatus]. Alauda, 71(3), 357-361.

Curley, S., Manne, L., \& Veit, R. (2020). Differential winter and breeding range shifts: Implications for avian migration distances. Diversity and Distributions, 26(4), 415-425.

Doren, B., \& Horton, K. (2018). A continental system for forecasting bird migration. Science, 361(6407), 1115-1118.

Doren, B., Horton, K., Dokter, A., Klinck, H., Elbin, S., \& Farnsworth, A. (2017). High-intensity urban light installation dramatically alters nocturnal bird migration. Proceedings of the National Academy of Sciences of the United States of America, 114(42), 11175-11180.

Drent, R., Fox, A., \& Stahl, J. (2006). Travelling to breed. Journal of Ornithology, 147(2), 122-134.

Dufour, P., Descamps, S., Chantepie, S., Renaud, J., Guéguen, M., Schiffers, K., Thuiller, W., \& Lavergne, S. (2020). Reconstructing the geographic and climatic origins of long-distance bird migrations, Journal of Biogeography, 47(1), $155-166$.

Feldman, A. S., \& Berezovikov, N. N. (2017). Novye sluchai kormleniya zhelny Dryocopus martius plodami yabloni sibirskoj Malus baccata v Semipalatinskom Priirtyshe [New cases of feeding Dryocopus martius with fruits of Siberian apple Malus baccata in Semipalatinsk Irtysh region]. Russian Journal of Ecology, 26(1514), 4398 4401 (in Russian).

Gubin, B. M. (2018). Pticy odnogo iz rajonov goroda Almaty [Birds of one of the districts of Almaty]. Russian Journal of Ecology, 27(1650), 3767-3803 (in Russian).

Helm, B., Doren, B. M., Hoffmann, D., \& Hoffmann, U. (2019). Evolutionary response to climate change in migratory pied flycatchers. Current Biology, 29, 3714-3719.

Karpov, F. F. (2017). Troficheskie svyazi ptic s drevesno-kustarnikovymi porodami $\mathrm{v}$ zelyonyh nasazhdeniyah goroda Almaty [Trophic relations of birds with trees and shrubs in green spaces of the city of Almaty]. Russian Journal of Ecology, 26(1476), 3090-3098 (in Russian).

Komarov, Y. E., \& Komarova, N. A. (2001). K gnezdovoj biologii chernogo drozda $\mathrm{v}$ nizhnej chasti gornogo lesnogo poyasa Severnoj Osetii [On the nesting biology of the blackbird in the lower part of the mountain forest belt of North Ossetia]. Caucasian Ornithological Bulletin, 13, 73-79 (in Russian).

Koshelev, V. A., \& Matrukhan, T. I. (2010). Rozmishennya i struktura ornitokompleksiv v agrolandshaftah Pivdnya Zaporizkoyi oblasti [Distribution and structure of omithological complexes in agricultural landscapes of the Zaporizhzhya region]. Newsletter of the Zaporizka National University, 1, 39-52 (in Russian).

Koshelev, V. A., Pakhomov, O. Y., \& Busel, V. A. (2020). The formation of sclerophilic ornythocomplexes in the quarries in the South of Ukraine and their conservation prospects. Ecology, Environment and Conservation, 26(1), 411419.

Kuzmenko, T. M. (2018). Ornatofauna v sostave agropromyshlennogo kompleksa Polissia i Lesostepi Ukrainy [Ornithofauna in the most critical agricultural landscapes Polissia and Forest-Steppe zone of Ukraine]. Schmalhausen Institute of Zoology, Kiev (in Ukrainian).

Lyakh, Y. G. (2018). Borovaya dich, ee prichastnost k rasprostraneniyu bakterialnyh infekcij [Boar game, its involvement in the spread of bacterial infections]. Journal of the Belarusian State University, Ecology, 3, 43-50 (in Russian). 
Lyapunov, V. V., Feldman, A. S., \& Berezovikov, N. N. (2017). Zhelna Dryocopus martius - novyj potrebitel plodov yabloni sibirskoj Malus baccata v Vostochno-Kazahstanskoj oblasti [Zhelna Dryocopus martius is a new consumer of Siberian apple Malus baccata in the East Kazakhstan region]. Russian Journal of Ecology, 26(1402), 502-507 (in Russian).

Mal'chevskij, A. S., \& Kadochnikov, N. P. (1953). Metodika prizhiznennogo izucheniya pitaniya gnezdovyh ptencov nasekomoyadnyh ptic [Methods of $i$ vivo study of nutrition of nesting chicks of insectivorous birds]. Zoological Journal, 32(2), 277-282 (in Russian).

McWilliams, S., Guglielmo, C., Pierce, B., \& Klaassen, M. (2004). Flying, fasting, and feeding in birds during migration: A nutritional and physiological ecology perspective. Joumal of Avian Biology, 35, 377-393.

Muheim, R., Schmaljohann, H., \& Alerstam, T. (2018). Feasibility of sun and magnetic compass mechanisms in avian long-distance migration. Movement Ecology, 6(8), 110-119.

Newton, I. (2006). Can conditions experienced during migration limit the population levels of birds? Journal of Omithology, 147(2), 146-166.

Nilsson, C., Dokter, A., Verlinden, L., Shamoun-Baranes, J., Schmid, B., Desmet, P., Bauer, S., Chapman, J., Alves, J., Stepanian, P., Sapir, N., Wainwright, C., Boos, M., Górska, A., Menz, M., Rodrigues, P., Leijnse, H., Zehtindjiev, P., Brabant, R., Haase, G., Weisshaupt, N., Ciach, M., \& Liechti, F. (2019). Revealing patterns of nocturnal migration using the European weather radar network. Ecography, 42(5), 876-886.

Norevik, G., Åkesson, S., Andersson, A., Bäckman, J., \& Hedenström, A. (2019). The lunar cycle drives migration of a nocturnal bird. PLoS Biology, 17(10), 88-98.

Oguchi, Y., Smith, R., \& Owen, J. (2017). Fruits and migrant health: Consequences of stopping over in exotic- vs. native-dominated shrublands on immune and antioxidant status of Swainson's thrushes and gray catbirds. Condor, 119(4), 800-816.

Olney, P. (1966). Berries and birds. Birds, 1(5), 98-99.

Panuccio, M., Dell'Omo, G., Bogliani, G., Catoni, C., \& Sapir, N. (2019). Migrating birds avoid flying through fog and low clouds. International Journal of Biometeorology, 63(2), 231-239.

Parrish, J. D. (1997). Pattems of frugivory and energetic condition in nearctic landbirds during autumn migration. Condor, 99(3), 681-697.

Parrish, J. D. (2000). Behavioral, energetic, and conservation implications of foraging plasticity during migration. Studies in Avian Biology, 20, 53-70.

Pereira, P., Godinho, C., Roque, I., Marques, A., Branco, M., \& Rabaça, J. (2014). Time to rethink the management intensity in a mediterranean oak woodland: The response of insectivorous birds and leaf-chewing defoliators as key groups in the forest ecosystem. Annals of Forest Science, 71(1), 25-32.

Petrovich, O. Z. (2014). Ptahi polezahisnih lisosmug v mezhah Voznesenskogo rajonu Mikolayivskoyi oblasti u gnizdovij period [Ptahs of useful lisosmugs in the boundaries of the Voznesensky district of the Mykolaiv region near the nest period]. Visti of the Biosphere Reserve Askania-Nova, 16, 46-55 (in Ukrainian).

Pisotska, V. V. (2018). Do ornitofauni polezahisnih lisosmug Harkivskoyi oblasti [To the avifauna of field protective forest belts of Kharkiv region]. Ecology and Noospherology, 30(1), 56-61 (in Ukrainian).

Prokofieva, I. V. (2001). Zabota o ptencah i pitanie popolznej S. europaea [Caring for chicks and feeding nuthatches S. europaea]. Russian Journal of Ecology, 10(168), 1019-1027 (in Russian).

Prokofieva, I. V. (2002). K ekologii sojki Garrulus glandarius v Leningradskoj oblasti [To the ecology of the jay Garrulus glandarius in the Leningrad region]. Russian Journal of Ecology, 11(172), 33-40 (in Russian).

Prokofieva, I. V. (2003). Pitanie vranovyh v letne-osennij period [Corvids nutrition in the summer-autumn period]. Russian Joumal of Ecology, 12(230), 814-821 (in Russian).

Prokofieva, I. V. (2005). Rezultaty sravneniya korma vorobinyh ptic v raznye po usloviyam gody [Comparison of food for passerine birds in different years]. Russian Journal of Ecology, 14(287), 42-425 (in Russian).
Ravkin, E. S., \& Chelintsev, N. G. (1990). Metodicheskiye rekomendatsii po kompleksnomu marshrutnomu uchetu ptits [Methodical recommendations for integrated route counting of birds]. Nature, Moscow (in Russian).

Rotics, S., Turjeman, S., Kaatz, M., Resheff, Y., Zurell, D., Sapir, N., Eggers, U., Fiedler, W., Flack, A., Jeltsch, F., Wikelski, M., \& Nathan, R. (2017). Wintering in Europe instead of Africa enhances juvenile survival in a long-distance migrant. Animal Behaviour, 126, 79-88.

Schmaljohann, H. (2018). Proximate mechanisms affecting seasonal differences in migration speed of avian species. Scientific Reports, 8(1), 1-9.

Shirihai, H., Gargallo, G., \& Helbig, A. (2001). Sylvia warblers. Identification, taxonomy and phylogeny of the genus Sylvia. A. \& C. Black, London.

Shupova, T. (2014). Adaptatsiya goristskoy tserkvi (Phoenicurus ochruros S. G. Gmelin) do otkrytiya v kiyevskoy aglomeratsii [Adaptations of black redstart (Phoenicurus ochruros S. G. Gmelin) to inhabit in Kyiv city metropolis]. Studia Biologica, 8(1), 187-196 (in Ukrainian).

Smallwood, K., \& Bell, D. (2020). Effects of wind turbine curtailment on bird and bat fatalities. Journal of Wildlife Management, 84(4), 685-696.

Smith, S., McPherson, K., Backer, J., Pierce, B., Podelesak, D., \& McWilliams, S. (2007). Fruit quality and consumption by songbirds during autumn migration. Wilson Jounmal of Omnitology, 119, 419-428.

Somveille, M. (2016). The global ecology of bird migration: Patterns and processes. Frontiers of Biogeography, 8(3), 1-6.

Somveille, M., Manica, A., \& Rodrigues, A. (2019). Where the wild birds go: Explaining the differences in migratory destinations across terrestrial bird species. Ecography, 42(2), 225-236.

Somveille, M., Rodrigues, A., \& Manica, A. (2015). Why do birds migrate? A macroecological perspective. Global Ecology and Biogeography, 24(6), $664-674$.

Somveille, M., Wikelski, M., Beyer, R., Rodrigues, A., Manica, A., \& Jetz, W. (2020). Simulation-based reconstruction of global bird migration over the past 50,000 years. Nature Communications, 11(1), 801-811.

Sorte, F., Fink, D., Buler, J., Farnsworth, A., \& Cabrera-Cruz, S. (2017). Seasonal associations with urban light pollution for nocturnally migrating bird populations. Global Change Biology, 23(11), 4609-4619.

Tattoni, C., Soardi, E., Prosser, F., Odasso, M., Zatelli, P., Ciolli, M. (2019). Fruit availability for migratory birds: A GIS approach. PeerJ, 7, e6394.

Thomas, D. (1979). Figs as food source of migrating garden warblers in Southern Portugal. Bird Study, 26, 187-191.

Trierweiler, C., Klaassen, R., Drent, R., Exo, K., Komdeur, J., Bairlein, F., \& Koks, B. (2014). Migratory connectivity and populationspecific migration routes in a long-distance migratory bird. Proceedings of the Royal Society, Biological Sciences, 281(1778), 20132897.

Turček, F. J. (1968). Die Verbreitung der Vogelkirche in den Wäldern durch Vogel. Waldnygiene, 7(5), 129-132.

Vardanis, Y., Klaassen, R., Strandberg, R., \& Alerstam, T. (2011). Individuality in bird migration: Routes and timing. Biology Letters, 7(4), 502-505.

Vasilevskaya, A. A. (2018). Netipichnoe kormovoe povedenie zhelny Dryocopus martius na severe Moskvy [Atypical feeding behavior of Dryocopus martius in northern Moscow]. Russian Journal of Ecology, 27(1581), 1255-1258 (in Russian)

Vilkov, E. (2013). Population trends in regular migrants as the basis for a prediction model for conservation of the birds of Eurasia. Russian Journal of Ecology, 44(2), 142-157.

Visser, M., Perdeck, A., van Balen, J., \& Both, C. (2009). Climate change leads to decreasing bird migration distances. Global Change Biology, 15(8), 1859 1865 .

Wolfe, J. D., Johnson, M. D., \& Ralph, C. J. (2014). Do birds select habitat or food resources? Nearctic-neotropic migrants in Northeastern Costa Rica. PLoS One, 9(1), e86221.

Zaifman, J., Shan, D., Ay, A., \& Jimenez, A. (2017). Shifts in bird migration timing in North American long-distance and short-distance migrants are associated with climate change. International Journal of Zoology, 2017, 6025646. 